\title{
Blue Ocean Strategy (BOS) Public Relations of Kampung Wisata Baluwarti Surakarta in Developing Village Branding
}

\author{
Prita Suci Nurcandrani ${ }^{1}$, Ade Tuti Turistiati ${ }^{2}$, Sefy Andhriany ${ }^{3}$, Dinda Intan Nurulina ${ }^{4}$ \\ 1,2,3,4 Prodi Ilmu Komunikasi, Fakultas Bisnis dan Sosial Universitas Amikom Purwokerto \\ E-mail: prita.suci@amikompurwokerto.ac.id ${ }^{1}$, ade.tuti@ amikompurwokerto.ac.id ${ }^{2 *}$, sefyandhriany09@ gmail, \\ dindaintangwlas@gmail.com \\ *corresponding author
}

ARTICLE INFO

Article history

Received 2020-08-29

Revised 2020-09-12

Accepted 2020-09-19

Keywords

Blue Ocean Strategy;

Public Relations;

Village Branding

\section{ABSTRACT}

This study aims to analyze how the Baluwarti Surakarta Tourism Village builds village branding. The components of the formation of village branding include the physical potential of the village that is unique, natural, rare, and has the concept of community empowerment. In formulating village branding, this study uses the Blue Ocean Strategy in which competition with other tourist villages is irrelevant. The use of digital branding is also associated with the village branding business in Baluwarti Tourism Village. The research was conducted from December 2019 to January 2020 (two months) and the research method was a descriptive qualitative. Data collection techniques used direct observation to the research locus and in-depth interviews with research informants. The results of this study indicate that Surakarta's Baluwarti Tourism Village needs to have a Public Relations whose role is to optimize the role of all stakeholders in achieving village branding, especially empowering the Baluwarti community and utilizing effective and efficient communication media.

\section{INTRODUCTION}

The term tourism comes from Sanskrit which comes from two syllables, namely 'pari' which means many or many times and 'tourism' which means travel or traveling. So, in simple terms, tourism is understood as a trip that is carried out many times (Widokarti \& Priansa, 2019). Meanwhile, according to (Meyers, 2009), tourism is a travel activity carried out by temporarily from the original place of residence to the destination area on the grounds that it is not to settle down or earn a living but only to fulfill curiosity, spend free time or holidays and other purposes. .

Nowadays, the tourism sector leads to the development and development of villages as tourist destinations. The target of village tourism does not only focus on attractions or tourist objects as a destination, but also takes into account the economic growth of the people living in the area. Tourism is also a form of integration between attractions, accommodation, and supporting facilities that are presented in a structure of community life that integrates with prevailing customs and traditions. The characteristics seen in a tourist village are that they have a tendency to be rural areas, have uniqueness, and have attractiveness as a tourist destination. Thus summarized in wikipedia that a tourism village is a rural area that can be utilized based on the ability of elements that have integrated tourism product attributes, where the village offers an overall atmosphere that has a theme by reflecting the authenticity of the village, both from the socio-cultural and economic aspects of life and daily customs that have architectural characteristics and village layout become a series of tourism activities (www.wikipedia.org, 2010)

Regarding the development of a tourism village, Dewa Putu Oka and Prasiasa and Dewa Ayu Diah Sri Widari in their article entitled Tourism Village Based on Empowerment, Partnership, and Institutional Strengthening in Terunyan Village Bali in 2019 summarized the components of tourism villages from various previous studies. Bashar and Ajloni (2012) in their 
study of the motivation of foreign tourists to travel to rural sites in Petra, Jordan stated that one of the attractions of tourists visiting rural areas is the availability of environmental facilities. Apart from the facilities aspect, Chiu, et al. (2016) in their research revealed that affective images are influenced by cognitive images and confirm the process of forming destination images. In line with this, in terms of the destination quality of a tourist village, Rajaratnam and Nair (2015) revealed that there are eight main attributes that influence destination quality, namely facilities, accessibility, logistics, experience, cleanliness, information, security and friendliness. Meanwhile, Chang and Tsai in their research entitled "Influences of The Cultural Implications and Tourism Attractiveness of Festival Tourism on Tourist", stated that the main factors that influence tourist attraction are implications and cultural integration that form new experiences for tourists. (Prasiasa \& Widari, 2019).

A number of main elements of tourism products in tourism marketing include three parts, namely: a) The attractiveness of a tourist destination, including the image imagined by tourists; b) Facilities owned by tourist destinations, including accommodation, food processing businesses, parking, transportation and recreation; c) Ease of reaching the tourist destination (Yuti, 2012)

Kampung Wisata is one of the tourism sectors in Indonesia which has developed quite well. An area that was originally just an ordinary village with a homogeneous population demographic is now starting to develop. Various instagramable spots are very easy to find when visiting a place, both natural and artificial. The growth in the number and quality of various tourist destinations is very fast, making tourism managers compete to provide the best for tourists, including managers of Baluwarti Tourism Village. However, the efforts made by the managers of Baluwarti Tourism Village have not achieved the expected results seen from the number of tourist visits.

Baluwarti has been a tourist village since August 2017. Baluwarti Tourism Village is a cultural heritage area with historical and cultural heritage in the city of Surakarta. The charm of Baluwarti lies in the neighborhood and the houses of its residents who live inside the palace walls which are 2 meters thick and 6 meters high. This tourist destination offers local wisdom which includes customs and the potential wealth of residents in the Baluwarti Village. In addition, the tourist village also introduced several other products, namely, typical Baluwarti culinary delights, arts and cultural performances, and quite interesting local crafts.

The Surakarta City Tourism Office has been working on a promotional strategy to build the Baluwarti village since 2017 by making printed brochures, utilizing social media, and utilizing the Creative Space Application, and by partnering with several tour and travel agents. According to the KWB Public Relations Division, tourists who come from within and outside the country, especially from the Netherlands. However, the number of visits was not as expected, namely at least 200 tourists per month.

The following is a table of tourist visits to Baluwarti Tourism Village from June to December 2918, and the types of programs / activities that were followed:

Table 1 Tourist Visit June-December 2019

\begin{tabular}{|c|l|l|c|}
\hline Month & \multicolumn{1}{|c|}{ Tourists Origin } & \multicolumn{1}{|c|}{ Type of Activities } & Total \\
\hline June & $\begin{array}{l}\text { Anggota GENPI Solo } \\
\text { (Blusukan Production) }\end{array}$ & $\begin{array}{l}\text { Seeing the production } \\
\text { of traditional cakes, } \\
\text { Javanese clothing and } \\
\text { historical buildings }\end{array}$ & 15 orang \\
\hline July & $\begin{array}{l}\text { Netherlands } \\
\text { (international) }\end{array}$ & Cooking Nasi Liwet & 10 orang \\
\hline July & $\begin{array}{l}\text { Netherlands } \\
\text { (international) }\end{array}$ & Cooking nasi Liwet & 10 orang \\
\hline
\end{tabular}




\begin{tabular}{|l|l|l|c|}
\hline August & $\begin{array}{l}\text { Local Government of } \\
\text { Tourism Officer-Dinas } \\
\text { Pariwisata Surakarta }\end{array}$ & $\begin{array}{l}\text { Arranging Janur, } \\
\text { Making Wiru and } \\
\text { Making Ratus }\end{array}$ & 40 orang \\
\hline September & $\begin{array}{l}\text { Netherlands } \\
\text { (international) }\end{array}$ & Cooking Nasi Liwet & 5 orang \\
\hline September & $\begin{array}{l}\text { Belgium } \\
\text { (international) }\end{array}$ & $\begin{array}{l}\text { Batik Education, } \\
\text { arranging Janur and } \\
\text { playing Karawitan }\end{array}$ & 5 orang \\
\hline October & UPW UNS & Arranging Janur & 40 orang \\
\hline October & $\begin{array}{l}\text { Soerakarta Walking } \\
\text { Tour }\end{array}$ & $\begin{array}{l}\text { Seeing historical } \\
\text { buildings }\end{array}$ & 50 orang \\
\hline October & $\begin{array}{l}\text { Netherlands } \\
\text { (international) }\end{array}$ & Cooking Nasi Liwet & 5 orang \\
\hline November & $\begin{array}{l}\text { Netherlands } \\
\text { (international) }\end{array}$ & Tooking Nasi Liwet & Total \\
\hline December & $\begin{array}{l}\text { Local Government of } \\
\text { Tourism Officer-Dinas } \\
\text { Pariwisata Surakarta }\end{array}$ & Cooking Nasi Liwet & 205 persons \\
\hline
\end{tabular}

Source: Public Relations of Kampung Wisata Baluwarti, 2019

The low level of tourist visits not only leads to a decrease in the nominal income of the KWB Surakarta destination, but has the potential to become a bigger problem, namely the sluggish economic growth of the people in the region. Sluggish economic growth can be a problem for the four hundred heads of families in Baluwarti Tourism Village. This is because they depend on the level of tourist visits.

The Public Relations sector is a very interesting field in the realm of tourism because this field is one of the entry points for tourism to destinations. The role of PR is indispensable for managing all MICE programs (Meeting, Incentive, Convention, and Exhibition), starting from planning and formulating MICE programs, funding issues explore, sponsorship, MICE marketing, MICE accommodation to implementation (MICE implementation), evaluation and planning. MICE event (Burhan, 2015). PR or commonly known as public relations (PR) is a part of an organizational structure that is tasked with establishing a harmonious relationship between institutions and the public. Public Relations in the tourism industry is one of the activities of the management and marketing functions carried out by business people in the tourism industry in establishing good, close, communicative and mutually facilitating relationships between business people in the tourism industry and their stakeholders, especially tourists as the main consumers of tourism ( Widokarti \& Priansa, 2019). The business actor / institution in this case is the Baluwarti Tourism Village, while the public consists of external and internal publics. The intended internal public is the public that is in the village organization Wisata Baluwarti. Meanwhile, the external public is the public outside the organization, namely tourists, the Surakarta city government, investors, the media, and private companies

Public Relations (PR) is a very crucial weapon or medium in convincing the market. Public Relations is in charge of managing the corporate brand in order to maintain the reputation of the company or organization in order to remain good in the eyes of consumers or the public. PR must have reliable skills and competencies to achieve the success of a business. This is in accordance with (Kotler \& Armstrong, 2012) which states that PR activities include various programs designed to support or protect the image of a business organization or the products of the business organization. Tench also stated that PR is: "The art and social science of analyzing trends, predicting their consequences, counseling organizational leaders, and implementing organization and the public interest (Tench \& Yeomans, 2009). 
Broom \& Smith identified the two most dominant PR roles, namely: 1) The Communication Manager or Communication Manager who has the main task of being an expert prescriber, communication facilitator, and problem-solving process facilitator. Public Relations is tasked with conducting research on a number of emerging problems and formulating a series of new programs to overcome these problems. In addition, PR must also be able to serve as a communication liaison and guardian of company goodwill in the eyes of the community; 2) The Communication Technician, PR must have technical and operational skills such as writing press releases, publications management, in addition to organizing activities, and creating website content. This technical capability should be more developed considering that a certain business goes through a complex level, phase, or lifecycle and demands an increasing PR capability. At the start-up stage, for example, in an effort to market PR products, at least one must have the ability to communicate interpersonal, create communication products, design websites and manage social media, and establish good relations with the media. (Suwatno \& Yuniarsih, 2017).

In the PR concept, a brand is something that actually creates a certain amount of awareness, reputation, etc. in the marketplace (Keller, 2013). Brand is also a symbol of embodiment of all information related to products or services. A brand usually consists of a name, a logo, and all visual elements such as images, typography, colors, and symbols. Brand in other words is a visualization of the image that wants to be implanted in the minds of consumers (Sudaryono, 2016). So, a brand is not just a name for a product or service, but a number of information that is in people's minds about a product or service with a particular brand. The term brand in tourism itself has its own study called the destination brand, where the destination product brand is the media and the message itself in the context and process of marketing communication.

In an effort to create a successful brand, it requires research, selection of effective and efficient strategies, and the right communication program. PR has similarities with the management function, namely assessing public attitudes, identifying policies and procedures of a person or organization in the public interest, and planning and carrying out a program of activities to gain public understanding and support. The focus of PR and branding when moving together is on developing public interest through PR activities and product advertising. Two actions carried out together, namely PR activities through branding and branding by promoting the brand. It is an art that combines two methods; convey information about the business related to the product as well as looking for possibilities to sell the product (Ulani, 2019).

In the digital era, communication programs to build brands are carried out through advertising and sales promotions, interactive marketing, holding events and cellular marketing (Keller, 2013). Digital branding is a marketing communication activity that aims to share information about a brand with the public through digital media such as the company website, social media Facebook, Instagram, and Youtube (Ulani, 2019). In digital branding, there are three tools, namely: 1) A website which is the earliest and most established form of online marketing communication is a website created by a company. The website should be updated frequently, and especially to existing customers offered as much specific information as possible. Website pages are made as attractive as possible and the latest technology should be used so that searchers' interest can be maintained, and brand messages can be communicated effectively; 2) Online advertising and videos. Internet advertising comes in forms like banners and text. One of its interactive characteristics allows the creation of two-way communication so that it can present the thoughts of each party (client and institution) who are having a satisfying dialogue. In fact, nowadays the development of advertisements on the internet is very rapid, exceeding the development of advertisements in newspapers; 3) Social media. Social media is playing an increasingly important role in brand communication due to its significant growth. Social media allows consumers to share text, images, audio and video. These media help promote innovation and brand information relevance. Everyone can express themselves freely on message walls, chat rooms and blogs so as to create a sense of community as well as 
encourage their involvement to actively interact. Social media offers great opportunities for marketers to connect with consumers in ways that were not possible before.

Business competition is now not only in the goods or services sector, but has penetrated the tourism sector. Hundreds or even thousands of tourist destinations offer tour packages that are actually almost similar but modified in such a way as to attract the attention of tourists to come. The tourist village has begun to grow and offers natural beauty that is wrapped in local wisdom so that it displays a destination that is felt to be visited. Public relations plays a very important role when actors in the tourism sector are competing. Various strategies and communication patterns are designed and implemented to be able to attract tourists to visit. Many tourist destinations still use the Red Ocean Strategy (ROS) to compete with other tourist destinations, but also not a few have switched to using the Blue Ocean Strategy (BOS) in implementing their tourism communications.

Table 2 Red Ocean vs Blue Ocean Strategy (Kim \& Mauborgne, 2017)

\begin{tabular}{|l|l|}
\hline \multicolumn{1}{|c|}{ Red Ocean Strategy } & \multicolumn{1}{c|}{ Blue Ocean Strategy } \\
\hline Complete in existing market space & Create uncontested market space \\
\hline Beat the competition & Make the competition irrelevant \\
\hline Exploit existing demand & Create and capture new demand \\
\hline Make the value-cost trade-off & Break the value-cost trade-off \\
\hline $\begin{array}{l}\text { Align the whole system of a firm `s activities with } \\
\text { its strategic choice of differentiation or low cost }\end{array}$ & $\begin{array}{l}\text { Align the whole system of a firm s activities in } \\
\text { pursuit of differentiation and low cost }\end{array}$ \\
\hline
\end{tabular}

The difference between the Red Ocean Strategy (ROS) and the Blue Ocean Strategy (BOS) is that ROS requires competition with other tourist destinations in the same market place arena. The risk of this ROS is quite heavy because you have to fight very hard. Meanwhile, BOS offers, creates, and captures new demand so that competition is no longer relevant.

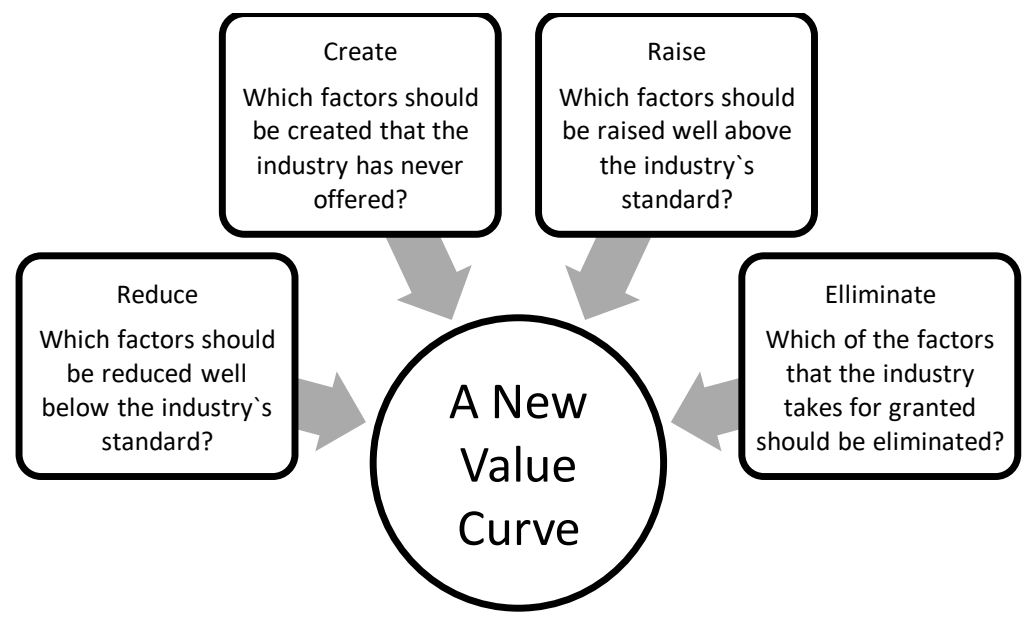

Fig. 1 The Four Action Framework (Kim \& Mauborgne, 2017)

In Eliminate's action, the PR strategy tries to remove variables or factors that have been played a lot in the tourism industry so that they do not play in the realm that has been done by competitors. Meanwhile, Reduce is in the form of reducing the level of bidding below competitors' standards. Furthermore, Create is a creative PR act to create something novelty in its business that competitors have not or have not done. In Raise's action, PR raises the level of offer above the standard given by the industry, which is of course based on the novelty or scarcity of the product that has been made.

Planning Theory, which was coined by Charles Berger, describes the process that a person takes in planning communication behavior. In communication psychology, the discussion of this theory becomes a separate topic that is quite interesting because it relates to how the human 
cognitive domain relates to their behavior, and how the plan will determine a number of human steps to achieve a goal. The steps taken are tiered. That is, certain actions are needed first so that further actions can be carried out (Littlejohn, 2017).

Message planning is related to a person's behavior and way of communicating considering that communication is very important and central to meeting social goals. The strength of the goals affects how complex the plans are. The plan theory states that the more knowledge and motivation one has, the more complex the plan will be.

Many goals are part of the planning process itself. The objectives that are part of the planning process are called metatujuan (metagoal) which functions to guide the various plans made. When efforts to achieve a goal encounter obstacles, there will be two possibilities for this. First, different special measures. Berger calls it the "low-level plan hierarchy change" or low-level plan hierarchy alternations. Second, more general action (abstract alternations). In some cases, people will usually resort to the first alternative, which is a change in the hierarchy of low-level plans.

There are times when obstacles cannot be predicted so that an action with a high-level strategy is needed. In this case, consideration is needed to slightly revise the goals to be achieved. Berger states that the adjustment of high or low level depends largely on how strong the motivation is.

Baluwarti Tourism Village has been using communication patterns and strategies commonly used by tourist destinations in general. According to the monthly tourist visit reports, there is no significant increase. This phenomenon becomes homework in itself, whether to maintain communication planning in the communication pattern or whether high-level strategic changes are needed.

Several previous studies have been conducted using the Blue Ocean Strategy as a strategy for developing a tourism village. Like Sitanggang in his thesis entitled "Evaluation of the Blue Ocean Strategy on Television Stations (Case Study on the Special Lantern Program on Global TV) in 2012", found a mapping of the market structure of the TV broadcasting industry in the form of oligopoly, as well as a linkage between the Blue Ocean Strategy and the market. structure, market conduct and performance. This research emphasizes the evaluation of the implementation of the Blue Ocean Strategy used by TV stations in a new program to determine the public's response regarding market structure, market conduct and performance (Sitanggang, 2012).

In addition, Apriliyati and Amanah Rakhim Syahida in their 2019 article entitled "PR Strategies in Forming the Village Branding for Tourism in Kutut Batu City", explained a series of strategies that PR can do in maximizing tourism potential in the intended destination. The article shows that the involvement of local residents and the creation of new media information content is a strategy that is quite good and possible to do (Apriliyanti \& Syahida, 2019).

Then Harsono and Suhandi in their article entitled "Tourism Village Development Strategies to Reduce Urbanization (Case Study of Cinyurup Village, Juhut Village, Karangtanjung District Pandeglang Regency) in 2019", describes several aspects, criteria, and the concept of a tourism village that is right for Cinyurup village. The results of this study state that the right theme for a tourism village is a unique, distinctive and healthy go green perspective based on horticultural excellence, natural beauty, and strong local culture. (Harsono \& Suhandi, 2019).

Blue Ocean Strategy is a new marketing strategy derived from Eastern philosophy which emphasizes harmony, balance and non-conflict. The Blue Ocean Strategy is considered a wise and smart strategy because it helps a lot in business development, especially among start-ups and SME businesses that tend to have limited capital and resources. BOS offers a formula for conducting product engineering called The Four Actions Framework. So this research uses the Blue Ocean Strategy Public Relations, with the aim of developing village branding, which is 
formulated in the question "How is the Blue Ocean Strategy (BOS) Public Relations of Kampung Wisata Baluwarti Surakarta in Building Village Branding?"

\section{METHOD}

This study uses a qualitative-descriptive method that describes situations and events in the field by describing in detail and in depth the actual conditions. The techniques used for data collection were observation and in-depth interviews with the Public Relations of Kampung Wisata Baluwarti Surakarta and 5 (five) local tourists from Surakarta who were visiting. The method of observation (observation research) is usually carried out to track systematically and directly communication symptoms related to social, political and cultural problems in society. For this purpose, the researcher is accompanied by PR KWB, attending and observing the phenomenon in KWB, collecting data using interviews to complement and support the concepts and theories needed in the research. Documentation in the form of photographs, leaflets, flyers and several other documents related to KWB.

The researcher triangulated the source to check the validity of the data. In this case, the researcher confirmed the Public Relations and the KWB promotion section. Time triangulation is done by asking the same thing to informants (Public Relations) at different times. This time triangulation was conducted to test the consistency of informants' answers.

\section{RESULTS AND DISCUSSION}

Baluwarti is the only sub-district that is very special because the entire population occupies the area of the Kasunanan Surakarta Palace. The sub-district is located in Pasar Kliwon Subdistrict, where there are also palace schools and historical buildings. Baluwarti is the only sub-district where one hundred percent of the population does not have a certificate (Magersari) and only has a residence permit in the Keraton. Housing in the Baluwarti area is grouped within the village based on their role in the Keraton.

Baluwarti Village consists of $12 \mathrm{RWs}$ with 3 RTs for each RW. The total population of Baluwarti is 7,120 people with 1,440 households. Baluwarti, which has an area of \pm 40.70 hectares, was inhabited by princes, sentana, and other nobles who were relatives of the king. In addition, the location is also occupied by several nayaka regents, regents, soldiers and courtiers, both men and women. The Baluwarti area is in the second circle after the Kedhaton wall, located between two large walls measuring 2 meters thick and 6 meters high. The people living in the Baluwarti area are bound by certain regulations. For example, their relations with communities outside Kori Brajanala, also called Kori (lawang) Gapit, were more limited because the kori was closed between 11:00 p.m. and 5:30 a.m. Furthermore, when entering Baluwarti they must obey certain rules

(https://id.wikipedia.org/wiki/Baluwarti, Pasar_Kliwon, Surakarta). 
The organizational structure in Baluwarti Tourism Village is as follows:

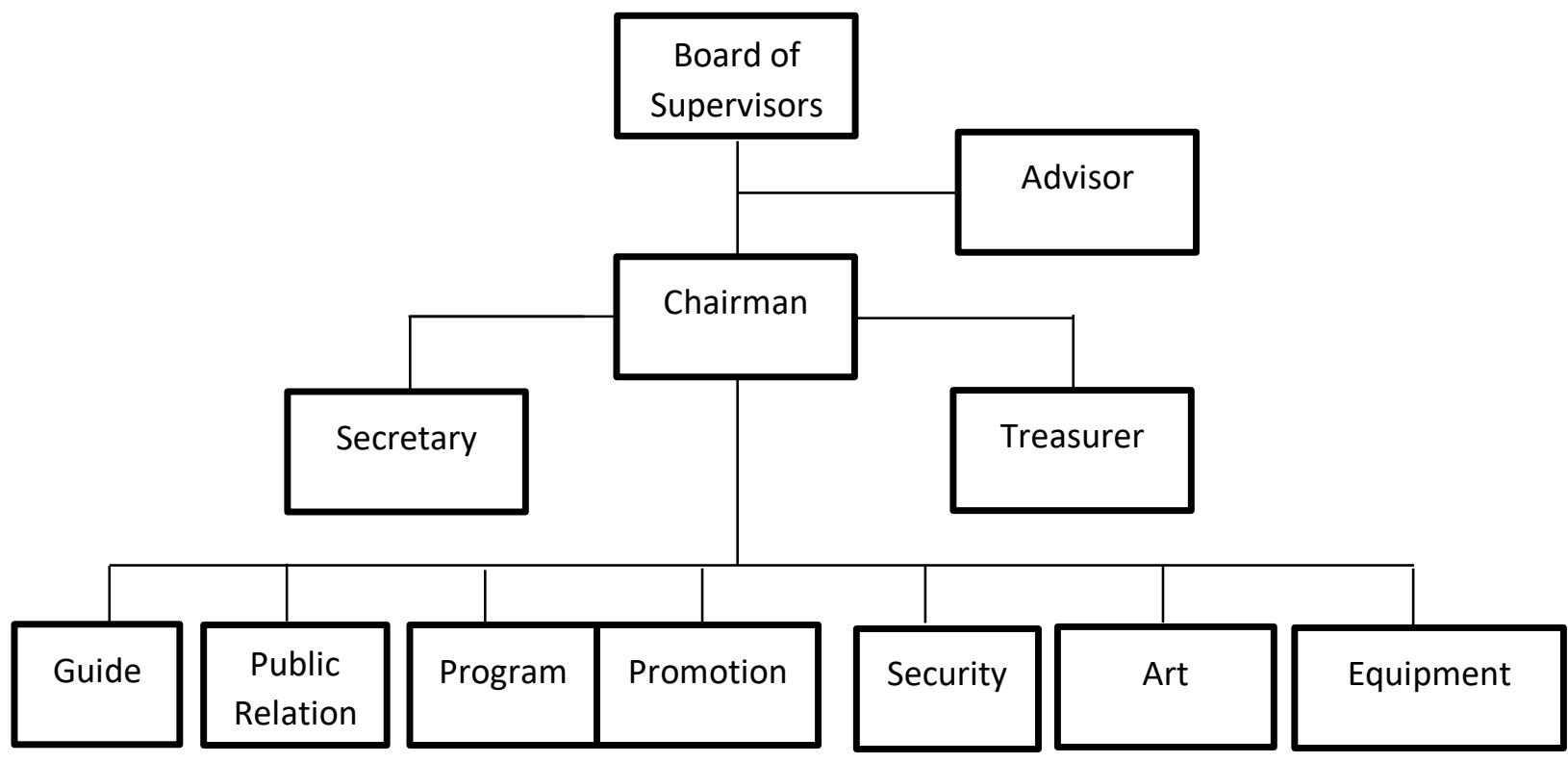

Fig. 2. Organizational Structure of Kampung Wisata Baluwarti

Kampung Wisata Baluwarti, which is part of the Kasunanan Palace, has tourism potential that is no less attractive than other tourist destinations. Tourists are treated to unique building forms in the Baluwarti neighborhood which are characterized by distinctive traditional architecture influenced by Javanese, European and Chinese architecture. A number of these buildings are quite interesting and instagramable spots for visitors to take pictures, as revealed by the following informant: AK tourist (22 years):

"Nowadays it is very difficult to find ancient buildings. Luckily I can still enjoy the beauty of the building in Baluwarti. " (AK, 22 years old, tourist from Surakarta)

Another traveler said:

"Apart from having fun taking pictures here, we can also hear directly from the historical community of these buildings." (AN, 20 years old, tourist from Surakarta)

Public Relations KWB formulated an educational program at several points where the ancient building stood. The benefits that tourists get are knowledge about the origin of Baluwarti, the implied meaning of the building's shape, the people who inhabit Baluwarti and why the building is still standing and quite well maintained today.

The aforementioned condition is one of the main attractions for tourists and can be a strength for the KWB brand. This is consistent with what Keller stated, that a brand is something that has actually created a certain amount of awareness, reputation, prominence and so on in the marketplace (Keller, 2013). In addition, optimizing the benefits of these ancient buildings includes the answer to the question why a village can be said to be a tourist village, which is rare, natural and unique. 


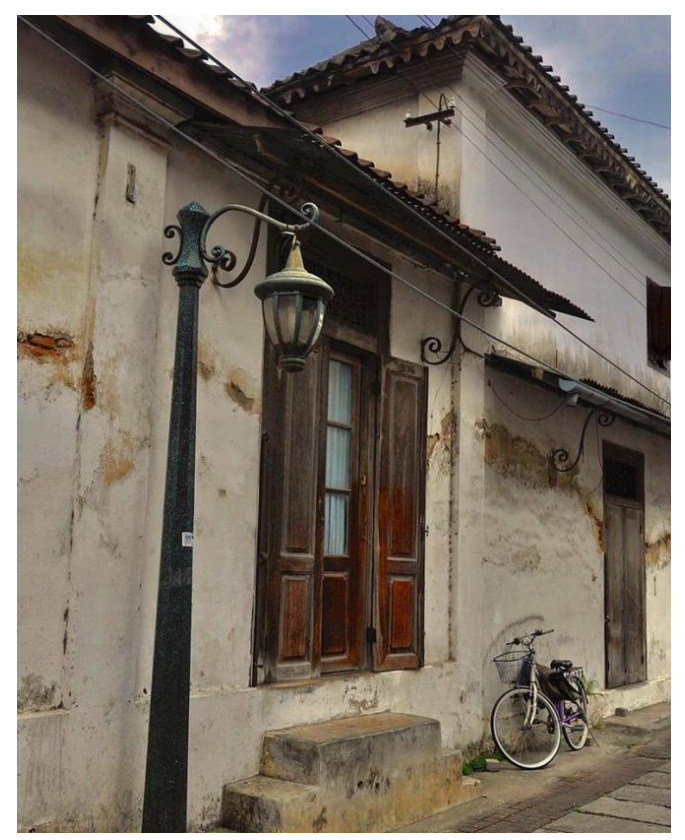

Fig.3 One of The Ancient Buildings Still Standing in Baluwarti.

KWB Public Relations also organizes various short training activities that both children and adults can participate in. The training offered is in the form of classical dance training, the art of gamelan playing the gamelan, arranging the coconut leaf, educating on ngadi salira ngadi clothes, imitating cloth, education on making masks, and making batik. Still in the education program, KWB apart from accepting tourists, also welcomes it as a location for outing activities for schools in the Surakarta area. In these training activities, the PR division involved the surrounding community to provide training to participants in community empowerment efforts as well as introducing Baluwarti community hospitality.

The KWB PR Division stated that:

"In accordance with the concept of a tourist village, we invite the Baluwarti community to take an active role in every training that is held. Of course, it is adjusted to the capacity and expertise of each member of the community so that they can provide training optimally. " (VC, 39 years old)

In the community empowerment program, the Public Relations division sees and explores the potential of Baluwarti residents. In accordance with the expertise and abilities of each member of the community, MSMEs were also developed based on Baluwarti's wealth. For community members who do not have expertise, the management of the Baluwarti Tourism Village provides training as initial capital so that the community can play an active role in every tourist visit.

Broom \& Smith stated that one of the dominant roles of PR is as a communication manager (Suwatno \& Yuniarsih, 2017). In this role, PR is tasked with conducting research on a number of emerging problems and formulating a series of new programs to overcome these problems. It is hoped that the more training the community will receive, the more diverse the training can be offered to tourists.

"In Baluwarti Tourism Village, we can choose the training program we want. The material giver was very patient and friendly in welcoming and teaching us. I happened to bring a large family group consisting of children and adults. " Said by tourists (AK, 22 years old, tourists from Surakarta) 
The training provided by the Baluwarti community to tourists is not only to introduce local culture, but also to provide other interesting experiences. In the leaf arrangement training, for example, tourists gain stringing skills, know the philosophy of why coconut leaves should be, why the shape must be according to standards, the use or benefits of arranging the leaves and training cooperation and tepa salira.

Another training is imitating cloth which can hone several abilities. In addition to knowing how to imitate cloth, tourists also get the philosophy of batik cloth motifs, the number and width of the pleats worn by ordinary people to those worn by the royal family. This training demands patience and gentleness when imitating fabrics.

Javanese culture, especially the Surakarta palace and its people, is not only visible to the eye, but contains a very deep meaning and even extends to the realm of Rosso. According to VC, KWB's PR Division, philosophy, life values and wisdom are actually reflected and embodied in every life practice and everything that is seen. VC added that after tourists receive training, it is hoped that they will know more about Indonesian culture, respect and even participate in preserving it.

Kampung Wisata Baluwarti also serves culinary tastes of the kings in the Keraton Surakarta which are distinctive, delicious, and unique dishes. Various snacks such as Ledre Intip Pisang Raja, Sekul Langgi, Wajik Klethik, Penyon and Jenang Suran. The concoctions of herbal drinks, Kencur Rice, Tamarind Sugar, Turmeric Asem, Wedang Ndongo are also served in Baluwarti Tourism Village. Tourists are also invited to see how to make and at the same time try to mix and cook directly in the kitchen, accompanied by skilled cooks at the Surakarta Palace.

The PR Division also organizes the Nasi Liwet Cooking Class program for foreign tourists. Nasi Liwet is a typical food that is very popular with the Sultan and the royal family.

"We want to nguri-uri (preserving) the special foods of the palace so that they are not lost and at the same time can be enjoyed by all groups, especially foreign tourists. delicious. Moreover, making liwet rice requires more patience and effort. Often when foreign tourists manage to make Nasi Liwet and taste it, they feel happy and very satisfied, "he added. (VC, 39 years old, PR Division).

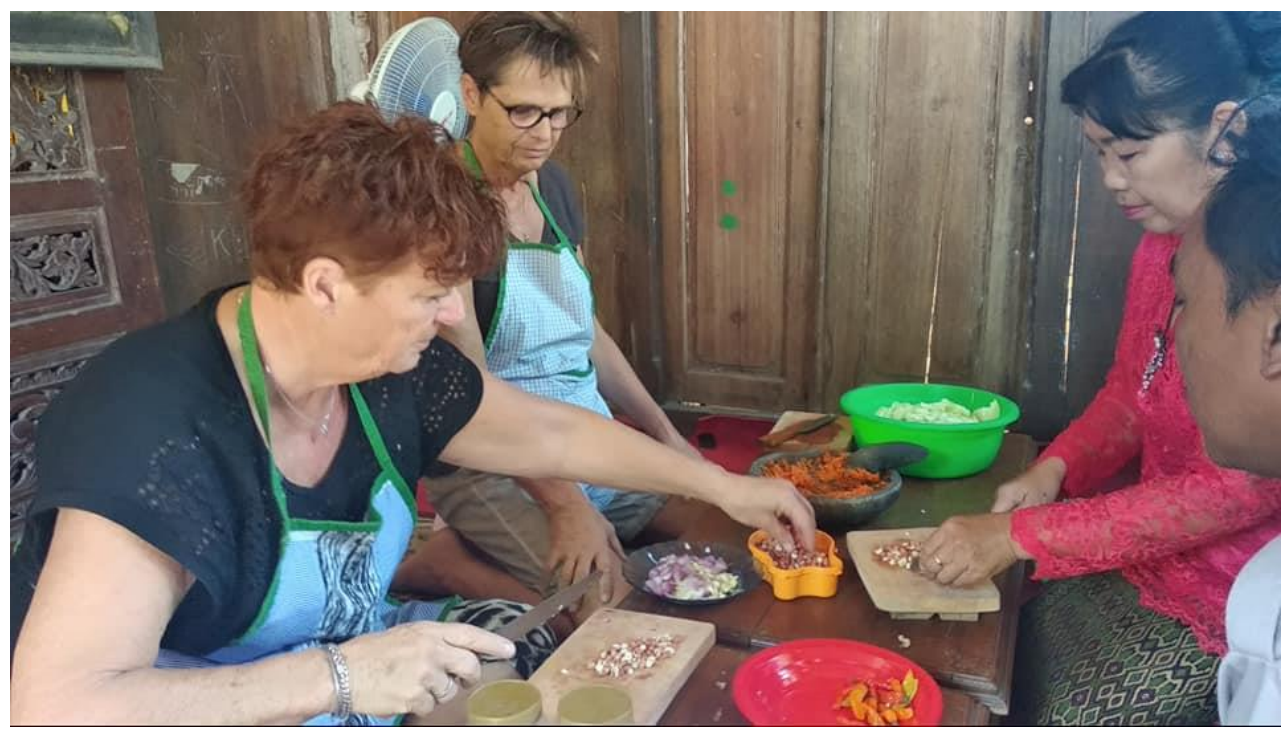




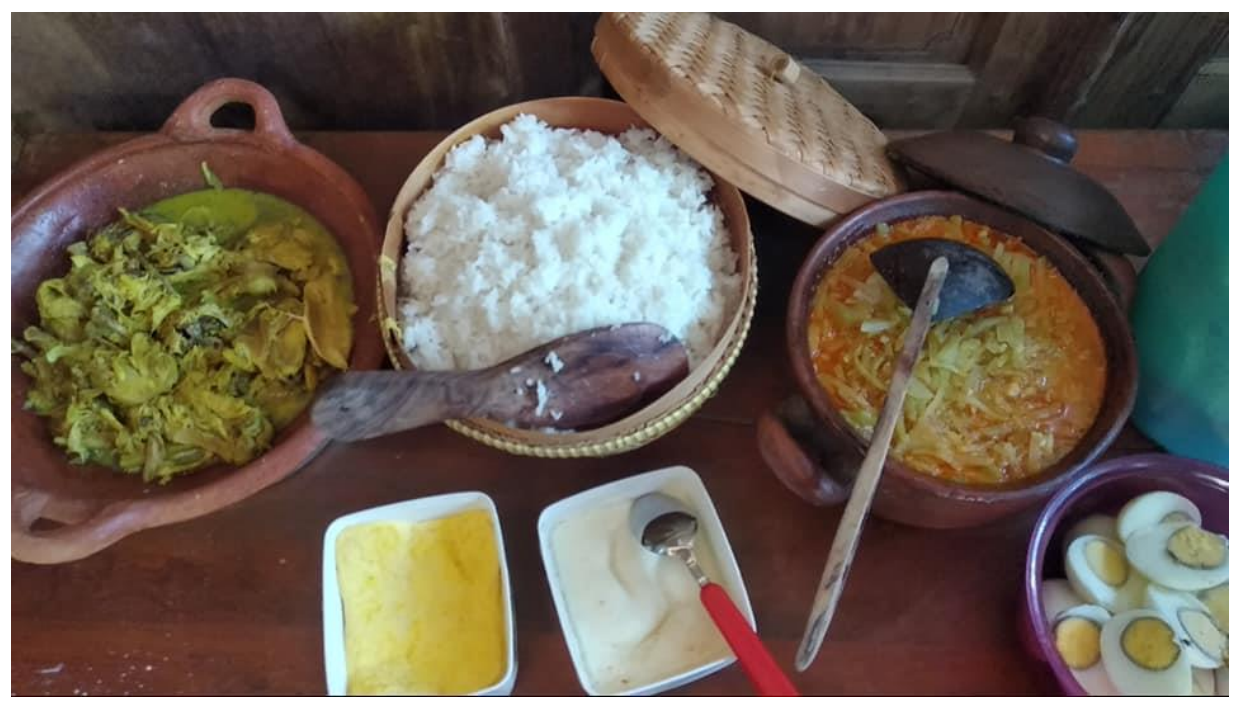

Fig. 4. Foreign tourists are making Nasi Liwet

(Documentation of Baluwarti Tourism Village PR)

The various kinds of potential and available cultural wealth mentioned above can be quite promising assets for village branding for KWB. Especially with the dependence of Baluwarti residents who rely on their daily lives on tourist visits, this problem has become a big homework for the PR division to invite tourists to visit and enjoy the various tourism products offered.

\section{The Four Actions Framework from Blue Ocean Strategy (BOS)}

In an effort to implement village branding, it is necessary to have sufficient strategic research and proper, effective and efficient communication from the PR division. Blue Ocean Strategy (BOS) is a strategy that is quite safe to do compared to the Red Ocean Strategy (ROS) even though it is full of innovation and creativity. BOS is an innovation and is a foresight of a concept, by looking at an opportunity in the market at the right time and at the right place, after seeing and observing the demands and desires of tourists. The first principle of BOS is to reconstruct market boundaries to move away from competition and create an unknown market place (Fatemeh, 2015). Management or in this case the PR division of KWB should be able to read a number of attractive commercial opportunities. This is in line with one of the dominant roles of public relations, namely as a communication manager (Suwatno \& Yuniarsih, 2017). As a communication manager, of course PR has the main task of being an expert prescriber, communication facilitator and problem-solving process facilitator. PR is in charge of conducting research on a number of emerging problems and formulating a series of new programs to overcome these problems.

The BOS concept is related to the Planning Theory expressed by Charles Berger (Littlejohn, 2017) that every work program must have a goal to be achieved. In the KWB case, the crucial goal to be achieved is to preserve the Baluwarti culture through community empowerment. Objectives that are part of the planning process are called metatujuan (metagoal) which serve to guide the various plans that are made. When efforts to achieve a goal encounter obstacles, there will be two possibilities for this. First, there are different special measures. Berger calls it the "low-level plan hierarchy change" or low-level plan hierarchy alternations. Second, is a more general action (abstract alternations). In some cases, usually people will do the first alternative, which is to take a different special action.

Blue Ocean Strategy is a way to avoid direct competition in the same matter, then look for other matters that are not owned by many competitors. The analysis is that the product or output that is sold must first be compared with other products that dominate the market in the industry (market leader). The Blue Ocean Strategy (BOS) uses unique actions called The Four Actions Framework: 


\section{Eliminate Action}

This action focuses on a number of factors or things that have not been done by the competitors. According to the PR division, VC (39 years old), so far the Baluwarti Tourism Village has the same tourism village concept as the Laweyan Batik Tourism Village (KWBL) and Kauman Batik Village (KBK). The similarity lies in empowering the community and raising their products in the form of MSMEs. The administrators of the three tourism villages have also been brought together in a Destination Management event for Tourist Destination Managers organized by the Surakarta City Government in May 2019 and Cyber Promo Training in June 2019.

Based on the similarity of the above concepts, the KWB Management considers that KWBL and KBK are its competitors. In fact, the concept adopted by KWB is different from the two tourist villages. In fact, this condition can be said that KWBL is the main competitor of KBK. This can be seen from the results of UMKM in the form of batik products that are sold to the public and training for tourists in the form of batik. Indeed, at KWB there was a training on imitating cloth which of course was complete with philosophies and historical values, but no batik products were sold. KWB sells hundred products, scrubs, traditional drinks and can bring home training works such as masks, nasi liwet, and twins mayang. In addition, there are other values obtained at KWB, namely tourists' knowledge of philosophy, life values, life practices and skills that they get directly from the Baluwarti community..

\section{Reduce Action}

The act of reducing here is to reduce activities that are less necessary or less desirable but of great expense. PR research and audits need to be carried out regularly in all aspects including human resources, physicality, attractions, easy access, to the price of each training. The Javanese cultural education tour, which includes the activities of arranging twins, karawitan, and batik, is priced at Rp. 75,000.00, imitating cloth Rp. 60,000.00. Trip on Baluwarti (canal) is priced from Rp. 350,000.00 which includes activities around the Baluwarti Village area using a pedicab, seeing the production process of traditional Javanese drinks, visiting historical buildings in Baluwarti Village, enjoying lunch, and receiving two training packages.

Another package offered by KWB is the Nasi Liwet cooking class for a minimum of three participants. The price for this training is differentiated between foreign tourists and domestic tourists. Local tourists each only pay Rp. 175,000.00 while for foreign tourists Rp. 275,000.00. There is also another package, namely traveling around the Baluwarti village area using Javanese clothes and horse-drawn carriages with a ticket price of Rp. 300,000.00 per participant. "The price is flexible and can change at any time," said PR KWB, VC (39 years).

The package price offered seems quite reasonable and in accordance with what they get. This was expressed by six domestic tourists, including ML (35 years old): "Compared to the benefits we get, the price is not too expensive either."

The issue of price is a sensitive issue for everyone, including in the tourism sector. Often times, tourists compare the benefits obtained with the price of admission tickets or tour packages between one destination and another. Tourists will not feel bad about paying higher prices, but expectations of these tourist destinations are achieved, and there is even a desire to visit again. At that point, Village Branding was actually achieved, and therefore PR sensitivity is needed in managing its tourist destinations well. Research and audits that are regularly carried out can become the basis for policies to continuously update and optimize the area and remove various things that are not needed or are no longer trending or have been copied by other tourist destinations..

\section{Raise Action}

Talking about Raise or increasing, of course, the emphasis on this action includes improvement. Improvement includes many aspects, such as ease of reaching destinations, ease of finding places of worship, cleaning toilets, and placing trash bins and cleaning. This looks 
simple, but it becomes something crucial when tourists cannot or find it very difficult to find it. Several tourist informants stated that the cleanliness at KWB was quite accommodated, as expressed by a tourist ML (35 years): "In KWB it is very easy to find a toilet, even the conditions are quite clean and well-maintained. It feels quite comfortable. "

Other improvements also include aspects of training services to tourists, including location and property, as well as aspects of service excellence. The training location is located in each production house, which consists of 12 points according to the training venue to be attended, namely the production of herbal medicine, keris production, wearing Javanese clothing, Javanese dancing, batik, wayang beber, karawitan and nembang, imitating cloth, making masks, arranging twins mayang, dance and gamelan, as well as cooking class Javanese cuisine, especially Nasi Liwet. It is not easy to manage these twelve points because one point includes the capabilities and expertise of human resources, availability of property, cleanliness of location and easy access to these points. Tourist satisfaction also varies according to their experience of traveling. ML (35 years) reiterated: "Many of the properties are dirty and unused, making it uncomfortable and very disturbing to see." Of course, this simple improvement is the joint responsibility of the Baluwarti residents, especially those who are responsible for the training point.

This maintenance must also be continuous, not only when there will be tourist visits. If Baluwarti's physical and human resource competencies are well accommodated, then the onestep Village Branding can easily be achieved. Furthermore, the PR division needs to formulate a business strategy to communicate it with tourists. In this case, the task of PR as a Communication Technician is required. Public Relations is required to have technical and operational skills such as writing press releases, publications management, and organizing activities and creating website content. This technical capability should be more developed considering that a certain business goes through a complex level, phase, or lifecycle and demands an increasing PR capability. At the start-up stage, for example, in an effort to market PR products, at least one must have the ability to communicate interpersonal, make communication products, design websites and manage social media, and establish good relations with the media.

In the digital era, communication programs to build brands are carried out through advertising and sales promotions, interactive marketing, holding events and cellular marketing (Keller, 2013). Digital branding is a marketing communication activity that aims to share information about a brand with the public through digital media such as the company web and social media Facebook, Instagram, and Youtube (Yunus, 2019). Meanwhile, KWB has used Facebook, Instagram, and Youtube as its promotional media. However, the utilization is still not optimal so that the results are not optimal either. Actually, the media is just a tool to communicate effectively with the communicants, but what is no less important is the content of the media.

Herein lies the importance of improving news content or features. The content for tourism village destinations can be in the form of the friendliness of its citizens, the uniqueness and characteristics of the village, the potential of natural resources to the series of events created by the tourism village. This content can be displayed in various promotional media and tailored to the target market, and one of them is social media. Social media is playing an increasingly important role in brand communication due to its rapid growth. Social media allows consumers to share text, images, audio and video. These media help promote innovation and brand information relevance. Everyone can express themselves freely on message walls, chat rooms and blogs so as to create a sense of community as well as encourage their involvement to actively interact. Social media offers great opportunities for marketers to connect with consumers in ways that were not possible before.

\section{Create Action}

At the stage or action of creating new things (create), of course, also speaks of branding efforts. It is said by (Keller, 2013) that: "a brand is something that has actually created a certain 
amount of awareness, reputation, prominence and so on in the marketplace". So, a brand is not just a name for a product or service, but a number of information that is in people's minds about a product or service with a particular brand. Brand is also related to consumer confidence in a product or service that is believed not only to meet their needs, but to provide better and guaranteed satisfaction. KWB requires a strong Village Branding where when tourists hear or see Baluwarti, what is on the mind of tourists is an attractive tourist destination and provides more benefits. In order to achieve a successful Village Branding, it is necessary to improve and create something new that is not found in other tourist villages. One simple thing that a tourist AY (55 years old) said: "If possible, adding a variety of traditional Javanese snacks around the entrance will be more attractive and can increase the income of Baluwarti Tourism Village."

The LA tourist (47 years) chimed in on the statement: "If possible there is a Member Card as well as a guest book so that it is easy to contact them to return to visit."

Based on the explanation above, one of the methods to achieve KWB village branding is to conduct surveys and interviews regularly with tourists and the results are raised in the KWB board discussion as a follow-up. This is what PR is an art as well as a science, it is flexible and can be implemented in stakeholders. At this stage or action, it can be seen in the definition of PR, "The art and social science of analyzing trends, predicting their consequences, counseling organizational leader, and implementing organization and the public interest. (Tench \& Yeomans, 2009).

In addition, PR can organize an event which is located and themed KWB, such as a photography competition, a website creation competition, feature writing and a video feature. This type of competition is clearly very beneficial for the KWB because every competition announcement that is disseminated through the media will be seen by the public, plus those who like photography will be interested in participating. Furthermore, each of the best works can be used by the PR division to promote and even establish village branding, of course, by prior agreement with the photographer. Creating an event like this does require careful planning and support from various parties, especially it requires a lot of money. As said by PR VC (39 years old): "We have never made an event, although in our minds we often come up with lots of ideas. Again, I collided with costs, which are certainly quite a lot and it seems that it is not possible to realize it yet."

This is where the role of PR is needed again, namely to use the relationship to help the program, with the benefits that can also be offered to the relationship. For example, by participating in financing the event program, the relationship may participate in promoting the product or service. For example, PR KWB can collaborate with the government, schools, universities, NGOs, or other private company groups.

Various kinds of other competitions can also be held, such as a mask making competition and a coconut arranging competition for school children, a competition for making snacks and herbal drinks for adults. Of course, these activities are associated with big events, such as the Birthday of the City of Surakarta, or even major events of the Keraton Surakarta. During the competition, PR again used the relationship with journalists to cover the event. Here are some of the benefits that can be taken by funders from the event, namely that they are allowed to hold promotions which are also covered by the media. This is the importance of the role of PR in establishing good relationships with various parties. This is in line with the opinion of Suwatno and Yuniarsih that in an effort to market PR products, you must have the ability to communicate interpersonal, make communication products, and establish good relations with the media. (Suwatno \& Yuniarsih, 2017).

\section{CONCLUSION}

Public Relations (PR) has a number of strategies to achieve the goals expected by the organization it represents. Likewise, the Baluwarti Tourism Village (KWB) has the aim of preserving Javanese culture, especially the culture around the Surakarta Palace area through

Prita Suci Nurcandrani (Blue Ocean Strategy (BOS) Public Relations of Kampung Wisata Baluwarti ...) 
empowering the surrounding community. Through BOS, everything that KWB can do to strengthen Village Branding and increase the level of tourist visits can be identified and examined.

Each person is homework for himself and the organization attached to it. The task of the KWB PR division becomes lighter when it empowers the community to take an active role in every KWB tourism activity. The budget for the concept of branding, promotion, and improvement of KWB can be reduced by utilizing the maintenance of good relations with stakeholders, of course with the benefits that can be obtained by relationships. This is where the role of Public Relations is very important, namely as a communication manager and communication technician.

\section{REFERENCES}

Apriliyanti, N., \& Syahida, A. (2019). Strategi Public Relations dalam Membentuk Village Branding Wisata Kungkuk Kota Batu. JISIP, Jurnal Ilmu Sosial Dan Ilmu Politik, 8(4). Retrieved from https://publikasi.unitri.ac.id/index.php/fisip/article/view/1955

Burhan, B. (2015). Komunikasi Pariwisata Jakarta. Jakarta: Prenada Group.

Fatemeh, A. (2015). Blue Ocean Strategy: Definitions and Frameworks in Advanced Social. Humanities and Management, 2(3), 122-125.

Harsono, P., \& Suhandi. (2019). Strategi Pengembangan Kampung Wisata untuk Mengurangi Urbanisasi (Studi Kasus Kampung Cinyurup Kelurahan Juhut Kecamatan Karangtanjung Kabupaten Pandeglang). Jurnal Manajemen STIE MUhammadiyah Palopo, 5(2). Retrieved from http://journal.stiem.ac.id/index.php/jurman/article/view/361/291

Keller, K. . (2013). Strategic Brand Management: Building, Measuring, and Managing Brand Equity. United States of America: Pearson.

Kim, W. C., \& Mauborgne, R. (2017). Blue Ocean Shift: Beyond Competing-Proven Steps to Inspire Confidence and Seize New Growth. New York: Hachette Books.

Kotler, P., \& Armstrong, G. (2012). Principles of Marketing. New Jersey: Pearson Prentice Hall, Inc.

Littlejohn, S. W. (2017). Theories of Human Communication. United States of America: Waveland Press.

Meyers, K. (2009). Pengertian Pariwisata. Jakarta: Unesco Office.

Prasiasa, D. P. O., \& Widari, D. A. D. S. (2019). Desa Wisata Berbasis Pemberdayaan, Kemitraan, dan Penguatan Kelembagaan Di Desa Terunyan, Bali. Jurnal Sosiologi USK (Media Pemikiran \& Aplikasi). https://doi.org/10.24815/jsu.v13i1.13923

Sitanggang, A. (2012). Evaluasi Blue Ocean Strategy pada Stasiun Televisi (Studi Kasus pada Program Special Lampion di Global TV). Universitas Indonesia.

Sudaryono. (2016). Manajemen Pemasaran. Yogyakarta: Andi.

Suwatno, \& Yuniarsih, T. (2017). Manajemen Sumber Daya Manusia. Bandung: Alfabeta.

Tench, R., \& Yeomans, L. (2009). Exploring Public Relations. United States of America: Prentice Hall. 
Ulani, Y. (2019). Digital Branding: Teori dan Praktik. Bandung: Remaja Rosdakarya.

Widokarti, J. R., \& Priansa, D. J. (2019). Komunikasi Pemasaran Terpadu. Bandung: Alfabeta.

Yuti, O. A. (2012). Perencanaan Strategi Pemasaran Daerah Tujuan Wisata. Jakarta: PT. Pradnya Paramita. 